\title{
Pretreatment of Marasmius sp. on Biopulping of Oil Palm Empty Fruit Bunches
}

\author{
Hendro Risdianto $^{1} \&$ Susi Sugesty ${ }^{1}$ \\ ${ }^{1}$ Center for Pulp and Paper (CPP), Ministry of Industry, Republic of Indonesia \\ Correspondence: Hendro Risdianto, Center for Pulp and Paper (CPP), Ministry of Industry, Jl. Raya \\ Dayeuhkolot 132, Bandung 40258, Indonesia. E-mail: hendrorisdianto@yahoo.com
}

Received: May 4, 2015

doi:10.5539/mas.v9n7p1
Accepted: June 5, 2015

Online Published: June 30, 2015

\begin{abstract}
White rot fungi have an ability to degrade lignin by employing lignin-degrading enzymes i.e Lignin Peroxidase, Manganese Peroxidase and Laccase. Therefore, the fungi can be utilized on the pretreatment of biomass in pulp making (biopulping) and biobleaching. In this study, the pretreatment using White Rot Fungi of Marasmius sp. has been conducted on the the Oil Palm Empty Fruit Bunches (EFBs). Marasmius sp. has been grown on EFBs for 30 days. The results showed that the lignin content could be removed by $35.94 \%$. However, cellulose and hemicelluloses relatively did not show any changes in the EFBs. From the pulping process, the pretreatment exhibited the Kappa Number of 31.10. Compared to no pretreatment of white rot fungi, the Kappa Number obtained was 38.63. This result demonstrated a promising process for a green pulp making.
\end{abstract}

Keywords: biopulping, Empty Fruit Bunches, lignin, Kappa Number, Marasmius sp.

\section{Introduction}

In the past few decades, there are intensive research on biopulping, a process where wood chips or other lignocellulosics materials are inoculated with naturally lignin-degrading fungus which possess the ability to selectively degrade woody materials prior to pulping (Kirk et al., 1992; Scott et al. 2001; Wan dan Li, 2012). These fungi originally produce enzymes (biological catalysts) which degrade lignin and fragment wood fibers to forms more readily digested. Lignin peroxidase, manganese peroxidase and laccase were reported as results from biopulping process on oil palm trunk using white rot fungus Trametes versicolor (Singh et al., 2013). The utilization of white rot fungus have several advantages such as energy-efficient, less chlorine consumption on bleaching process, and reduce the pollution to the environment (Yadav et al., 2010). A promising white rot fungus Marasmius sp. secreted extracelluler laccase enzyme that degrade lignin in black liquor and unbleached kraft pulp (Risdianto et al., 2007; Risdianto et al., 2011). In addition, Eucalyptus grandis wood chips treated by Ceriporiopsis subvermispora on a 50-tonne pilot-plant demonstrated an energy saving in laboratory and mill-scale biopulping (Ferraz et al., 2008).

Indonesia is the largest of palm oil producer in the world. Crude Palm Oil (CPO) is the main product of palm oil industries. In 2012, Indonesia has produced 26.5 milion metric tonnes of CPO (www.indonesia-investments.com). From that production, the EFBs generated was around to 27.7 million metric tonnes (Visvanathan et al., 2009). Biomass waste of empty fruit bunches is yielded from a conversion of Fresh Fruit Bunches (FFBs) into CPO. The EFB is in large amount and usually incinerated at the plant site which could causes air pollution. EFBs of palm oil contains cellulose (37.26 - 40.79\%), hemicellulose (14.62 - 29.4\%), lignin (22.67 - 31.68\%), and extractives (1.34 - 3.30\%) (Erwinsyah et al., 2012; Sudiyani et al., 2013). The fiber length of EFBs is approximately $1.11 \mathrm{~mm}$ and classified as a short fiber. The EFBs pulp can be mixed with old corugated containers (OCC) to produce kraft liner and corrugating medium paper (Erwinsyah et al., 2012)

Due to its content and amount, the EFBs has a great potential as a material for pulp and papermaking. The challenges of the utilization of this nonwood materials for paper making are raised (Daud and Law, 2011). It is also triggered by the fact that increase of demand for paper production and limited wood resources hence there are efforts to find a new resources of non-wood materials for pulp and paper making. EFBs is one of the promising non-wood materials in Indonesia for pulp and paper making. This paper focused on the biopulping process of a promising non-wood material Empty Fruit Bunches employing Marasmius sp. as a lignin-degrading fungus. 


\section{Method}

\section{Microorganism}

The white rot fungus Marasmius sp. was obtained from Laboratory of Microbiology and Bioprocess Technology, Department of Chemical Engineering, Institut Teknologi Bandung, Indonesia. The strain was maintained on Potato Dextrose Agar (PDA) medium in the Petri dish and incubated for 7 days at $28^{\circ} \mathrm{C}$. The seven days age of stock culture was stored at $4^{\circ} \mathrm{C}$ until it was used.

\section{Lignocellulosic material}

The empty fruit bunches was obtained from plantation in South Sumatera. The EFBs was chopped in length around $5 \mathrm{~cm}$.

\section{Biopulping}

A 250 grams of EFB chopped was impregnated by $250 \mathrm{~mL}$ of modified Kirk medium in heat resistant plastic bag, consisting of glucose $10 \mathrm{~g} / \mathrm{L}, \mathrm{KH}_{2} \mathrm{PO}_{4} 1.7 \mathrm{~g} / \mathrm{L}, \mathrm{MgSO}_{4} .7 \mathrm{H}_{2} \mathrm{O} 0.4 \mathrm{~g} / \mathrm{L}, \mathrm{CaCl}_{2} 0.09 \mathrm{~g} / \mathrm{L}$, sodium acetate $2.3 \mathrm{~g} / \mathrm{L}$, diammonium tartrate $0.4 \mathrm{~g} / \mathrm{L}, \mathrm{MnCl}_{2} 0.02 \mathrm{~g} / \mathrm{L}$, yeast extract $0.3 \mathrm{~g} / \mathrm{L}, \mathrm{CuSO}_{4} .7 \mathrm{H}_{2} \mathrm{O} 0.01 \mathrm{~g} / \mathrm{L}, \mathrm{H}_{2} \mathrm{MoO}_{4} 0.007 \mathrm{~g} / \mathrm{L}$, $\mathrm{MnSO}_{4} \cdot 4 \mathrm{H}_{2} \mathrm{O} 0.01 \mathrm{~g} / \mathrm{L}, \mathrm{ZnSO}_{4} .7 \mathrm{H}_{2} \mathrm{O} 0.006 \mathrm{~g} / \mathrm{L}$ and $\mathrm{Fe}_{2}\left(\mathrm{SO}_{4}\right)_{3} 0.007 \mathrm{~g} / \mathrm{L}$. The EFBs and medium in plastic bag were steam sterilised in autoclave at $120^{\circ} \mathrm{C}$ for 20 minutes. Then, the EFBs and medium were allowed to cool down. The inoculum size of $1.5 \mathrm{~cm} \times 1.5 \mathrm{~cm}$ in total area of $63 \mathrm{~cm}^{2}$ was transferred aseptically to the sterilised EFBs. Incubation was performed in room temperature $\left( \pm 28^{\circ} \mathrm{C}\right)$ for 30 days. Every 10 days, sample was taken from a bag of cultures to analyse lignin, hemicellulose and total cellulose.

\section{Pulp making}

The treated EFBs was pulped by soda process in a digester with the following conditions: (a) Active Alkali was $12 \%$ and $18 \%$, solid to liquor ratio was $1: 4$, temperature was $140^{\circ} \mathrm{C}$, and total time was 3 hours (the to time and at time was 1.5 hours, respectively). The brown stock from digester was defiberated in fiber separator for 20 minutes, and then washed by water. The stock was then filterred by using flat screen and pressed to determine water content and the Kappa number. To evaluate the effectiveness of biopulping process, pulp was also made from EFBs in similar pulp making condition but no fungus treatment.

\section{Results and Discussion}

Marasmius sp. was well visible sign of growth on Empty Fruit Bunches as shown in Fig. 1. It is indicated that fungus can uptake the medium in substrate (EFBs) and bind it. Biopulping process is similar to the Solid state culture/fermentation. Marasmius sp. also was assisted by chopped EFBs due to the enhancement of surface area. Niladevi et al. (2007) revealed that surface area was one of the physical properties of substrate that influence the growth of fungus in Solid State Fermentation (SSF). This biopulping process was conducted at room temperature $\left( \pm 28^{\circ} \mathrm{C}\right)$. This proscess is similar to Solid State Fermentation (SSF) process. Pandey et al. (2008) and Risdianto et al. (2010), reported that SSF usually was performed by meshopilic microorganism at temperature range of 20 $50^{\circ} \mathrm{C}$. Fungus pretreated on biomass makes it porous and soft (Singhal, 2008).

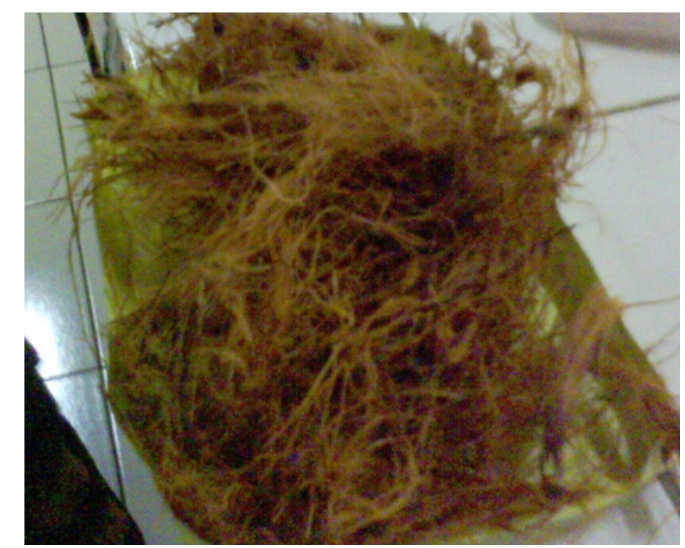

(A) initial condition

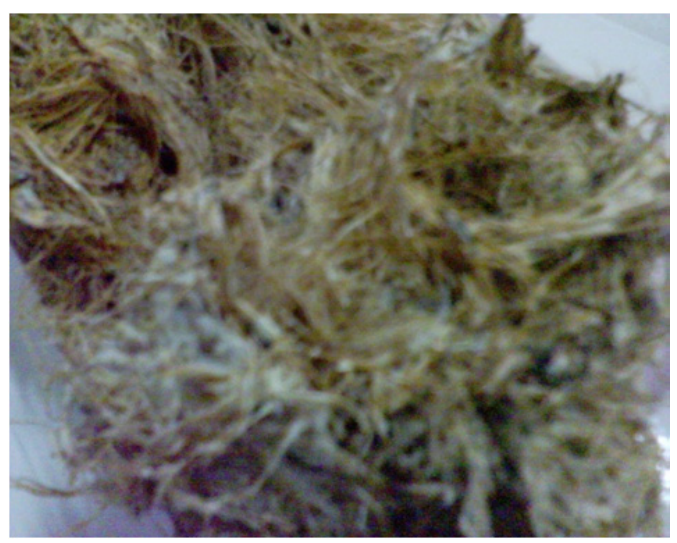

(B) day 30

Figure 1. The growth of Marasmius sp. on Empty Fruit Bunches 
The eficacy of Marasmius sp on biopulping was indicated by the reduction of lignin content during the incubation. As shown in Fig. 2, lignin content was linearly decrease. The initial lignin content was $24.25 \%$ and at the end of incubation time (day of 30) exhibited at value of $15.54 \%$. It means that Marasmius sp. employed in this study has a great ability to degrade lignin in EFBs. Marasmius sp. degraded lignin by secreting enzymes such as lignin peroxidase, manganese peroxidase and laccase. Yadav et al. (2010) revealed that the reduction of lignin content as a result of the action of lignin-degrading enzymes secreted by the fungi. The lignin biodegradation mechanism has been clearly described by Martinez et al. (2005). Laccase production in the cultures of Marasmius sp. began on day $3(51.04 \mathrm{U} / \mathrm{L})$ and reached maximum activity at day $8(330.07 \mathrm{U} / \mathrm{L})$ on the EFBs substrate (Risdianto et al., 2012). Glucose in the medium was consumed to growth and produce laccase for lignin degradation (Risdianto et al., 2010). Laccase secreted by whie rot fungi degrade non phenolic lignin compound in absence of mediator (Octavio et al., 2006; Camamero et al., 2007). The lignin degradation is oxidative in nature and occurred in aerobic process. For biopulping process, selective lignin degradation is required. Thus, fungi having robust ligninase system and deficient cellulolytic activity are suitable for biopulping (Singhal, 2008).

The incubation time for the fungal treatment was 30 days, and this is relatively a long period for a process at industrial scale. However, the fungal treatment gave several advantages such as energy-efficient by reducing aboput 30\% in refining process (Scott et al, 1998), less chlorine consumption on bleaching process, and reduces the pollution to the environment (Yadav et al., 2010). To achieve that advantages, Scott et al (1998) has proposes a biopulping process consist of decontamination, cooling, inoculation and incubation unit prior to pulping process.

Reducing lignin content give a great advantage for the pulp making due to lowering the cooking chemicals. The fungus treatment of lignocellulosic materials usually followed by the cooking using chemicals to obtained an unbleached pulp. From this study, the reduction of lignin was $35.94 \%$ of initial lignin content. An in line study on biopulping conducted by Singh et al. (2013) resulted the lignin content in Oil Palm Trunk (OPT) chips was determined to be $20.55 \%$ but was reduced by fungal treatments to the value of $9.35 \%$ after 28 days of incubation.

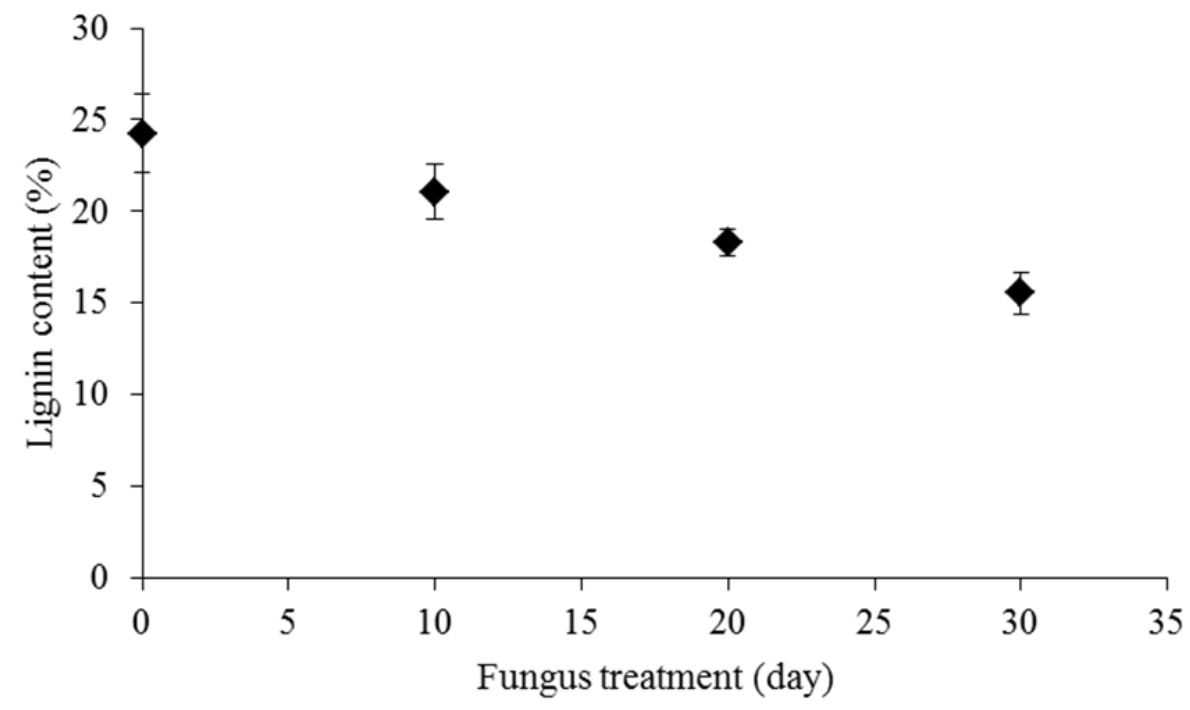

Figure 2. Lignin content in EFBs during treatment by Marasmius sp.

The analysis of hemicellulose after 30 days of biopulping process is presented in Fig. 3. The hemicellulose content in EFBs was determined to be $28.53 \%$. During the biopulping process, the hemicellulose content is relatively constant. At the end of biopulping process, hemicellulose content was detected at level $26.95 \%$. By using the ANOVA (Analysis of Varian), there is no different in significance for the hemicellulose content during biopulping indicated by $\mathrm{p}$ value was $0.64(\mathrm{p}>0.05)$. It means that Marasmius sp. selectively degrade lignin in EFBs. Nazarpour et al. (2013) found by the FTIR analysis that there was chemical changes during incubation of rubberwood by Ceriporiopsis subvermispora i.e lignin degradation but only a little change on carbohydrate degradation. The high selectivity for lignin degradation suggests that the fungus secrete a higher activity of lignin-degrading enzymes than cellulose and hemicellulose, and is therefore white rot fungus treatment is 
suitable for the biopulping process (Singh et al., 2013).

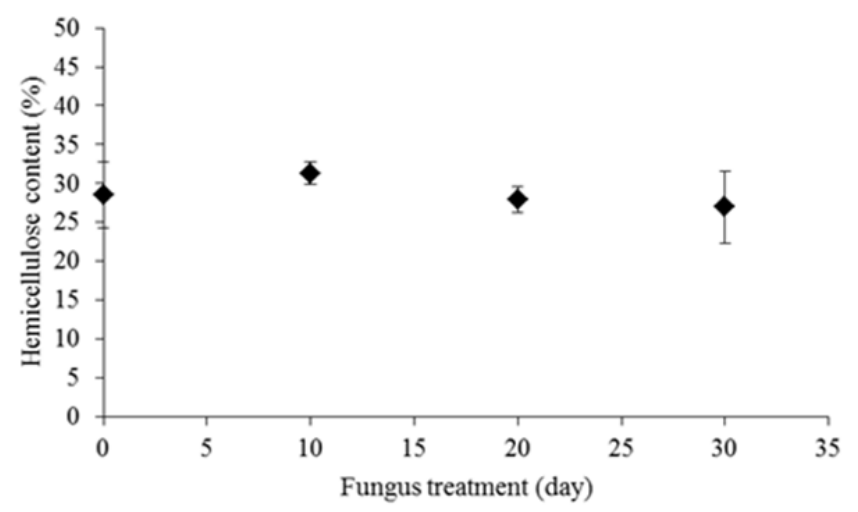

Figure 3. Hemicellulose content in EFBs during treatment by Marasmius sp.

The decreasing of lignin content in EFBs gave an important role for the further stage of pulpmaking. Lower lignin content can save the cooking chemicals in pulpmaking and therefore reduce the load of pollutant to be treated in waste water treatment plant. However, cellulose and hemicellulose are the main component that expected in high level due to the strenght of pulp and paper depend on these components. Comparison to other studies shows that the reduction of lignin content in this study is high around $35.94 \%$ as presented in Table 1 .

Table 1. Comparison to other studies of microorganism pretreated on biomass

\begin{tabular}{|c|c|c|c|c|}
\hline \multirow[b]{2}{*}{ Material } & \multicolumn{2}{|c|}{ Lignin content $(\%)$} & \multirow[b]{2}{*}{$\begin{array}{r}\% \\
\text { Reduction }\end{array}$} & \multirow[b]{2}{*}{ Reference } \\
\hline & Initial & $\begin{array}{r}\text { After } \\
\text { pretreated }\end{array}$ & & \\
\hline $\begin{array}{l}\text { Bagasse pretreated by Ceriporiopsis subvermispora ( } 2 \\
\text { weeks/14 days) }\end{array}$ & 20.1 & 19.3 & & $\begin{array}{r}\text { Bajpai et al., } \\
2004\end{array}$ \\
\hline $\begin{array}{l}\text { Mixed chips of Eucalyptus and poplar wood pretreated by } \\
\text { Ceriporiopsis subvermispora ( } 3 \text { weeks } / 21 \text { days) }\end{array}$ & 27.70 & 26.40 & 4.69 & $\begin{array}{r}\text { Yadav et al., } \\
2010\end{array}$ \\
\hline $\begin{array}{l}\text { Acacia mangium pretreated by Trametes versicolor ( } 60 \\
\text { days) }\end{array}$ & - & - & 26.9 & $\begin{array}{r}\text { Liew et al., } \\
2011\end{array}$ \\
\hline $\begin{array}{l}\text { Oil Palm Trunk (OPT) pretreated by Trametes versicolor } \\
\text { ( } 28 \text { days) }\end{array}$ & 20.55 & 9.35 & 54.50 & $\begin{array}{r}\text { Singh et al., } \\
2013\end{array}$ \\
\hline $\begin{array}{l}\text { Empty Fruit Bunches pretreated by Marasmius sp. ( } 30 \\
\text { days) }\end{array}$ & 24.26 & 15.54 & 35.94 & This study \\
\hline
\end{tabular}

After pretreated by Marasmius sp, EFBs was subjected to chemical cooking in digester to enhance the lignin degradation to the desired Kappa Number. Kappa number is an indirect measurement of lignin content in pulp m (Casey,1980). Higher Kappa number means lignin content is at high content. Sodium hydroxide $(\mathrm{NaOH})$ was used as chemical cooking due to it is a powerfull swelling agent for lignocellulosic materials that having low lignin content such as hardwood and nonwood plants. The alkali charge is one factor that gives a high effect in the soda pulping process (Ibrahim et al, 2011). Alkali charge of $20-30 \%$ was performed in the pulping process of oil-palm frond-fiber (Wanrosli et al, 2004a) and oil palm empty fruit bunch fibres (Wanrosli et al, 2004b). In this study, a lower alkali charge of $12 \%$ and $18 \%$ was used due to the EFBs has been treated by Marasmius sp which can degrade lignin content prior to soda pulping process.

At the active alkali (AA) $18 \%$, the Kappa number of EFBs pulp pretreated by Marasmius sp. was detected at value of 31.1. While Kappa number of pulp of control EFBs (no fungus pretreatment) was higher at value of 38.6 as shown in Figure. 4. A similar results was observed in biopulping of Eucalyptus wood (Eucalyptus grandis) by Cryptococcus albidus. The Kappa number of pulp of control and treated wood were 21 and 17, respectively (Singhal et al., 2013). When the EFBs pretreated was pulped by using Active Alkali $12 \%$ showed an increase Kappa Number of 44.22. The low active alkali resulted higher Kappa number which might be due to slow reactive penetration to the fiber and dissolve lignin (Ibrahim et al, 2011). From this study, pretreatments 
with Marasmius sp. can reduce the cooking chemical consumption on pulp making that can be used as an alternative pulp manufacturing process more environmentally friendly.

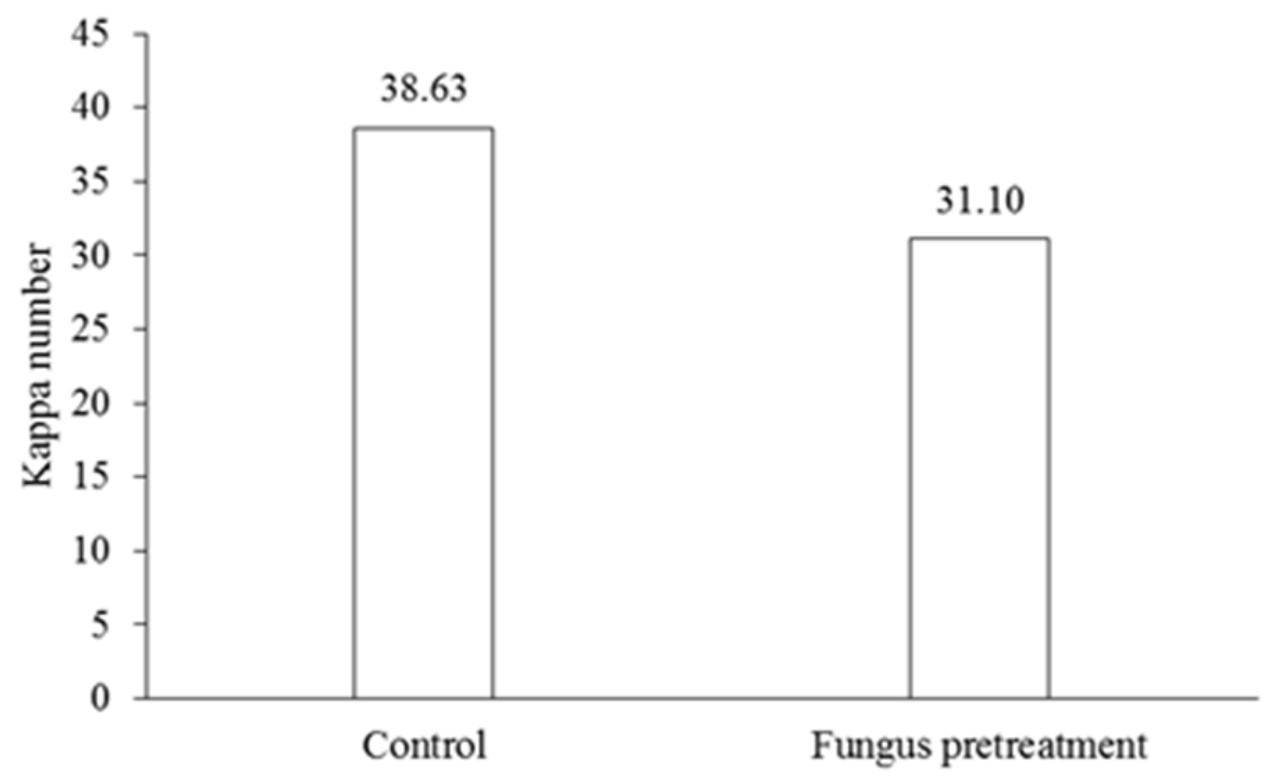

Figure 4. Kappa number of pulp

\section{Conclusion}

Marasmius sp. grew well in Empty Fruit Bunch for the pretreatment process and reduce lignin of $35.94 \%$ for 30 days. The Kappa Number of untreated EFBs by Marasmius sp. was 38.63 and for treated was 31.10. Therefore, Marasmius sp. has a great potential to be used in a green pulp making process.

\section{Acknowledgments}

Authors would like to thank to the Center for Pulp and Paper (CPP) for the funding and our colleagues at CPP for the support and encouragement.

\section{References}

Bajpai, P., Mishra, S. P., Mishra, O. P., Kumar, S., \& Bajpai, P. K. (2004). Biochemical Pulping of Bagasse. Biotechnol. Prog., 20, 1270-1272. http://dx.doi.org/10.1021/bp040005q

Camamero, S., Ibarra, D., Martínez, A. T., Romero, J., Gutiérrez, A., \& del Río, J. C. (2007). Paper pulp delignification using laccase and natural mediators. Enzyme and Microbial Technology, 40, 1264-1271. http://dx.doi.org/10.1016/j.enzmictec.2006.09.016

Daud, W. R. W., \& Law, K. N. ((2011). Oil palm fibers as papermaking material: Potential and challenges. Bioresources, 6(1), 901-917.

Erwinsyah, Sugesty, S., \& Hidayat, T. (2012). Kraft liner and corrugating medium from mechanical pulp empty fruit bunches of palm oil. Jurnal Selulosa, 2, 8-13.

Ferraz, A., Guerra, A., Mendonça, R., Masarin, F., Vicentim, M. P., Aguiar, A., \& Pavan, P. C. (2008). Technological advances and mechanistic basis for fungal biopulping. Enzyme and Microbial Technology, 43, 178-185. http://dx.doi.org/10.1016/j.enzmictec.2007.10.002

Ibrahim, M., Wanrosli, W. D., \& Law, K. N. (2011). Comparative properties of soda pulps from stalk, bast, and core of Malaysian grown kenaf. Bioresources, 6(4), 5074-5085.

Kirk, T. K., Burgess, R. R., \& Koning Jr., J. W. (1992) Use of fungi in pulping wood: an overview of biopulping research. In Leatham, G.F., Frontiers in industrial mycologi. Springer US. http://dx.doi.org/10.1007/978-1-4684-7112-0_7

Liew, C. Y., Husaini, A., Muid, S., Liew, K. C., \& Roslan, H. A. (2011). Lignin biodegradation and ligninolytic enzyme studies during biopulping of Acacia mangium wood chips by tropical white rot fungi. World 
Journal of Microbiology and Biotechnology, 27(6), 1457-1468. http://dx.doi.org/10.1007/s11274-010-0598-x

Martinez, A. T., Speranza, M., Ruiz-Duenas, F. J., Ferreira, P., Camarero, S., Guillen, F., ... Rio, J. C. (2005). Biodegradation of lignocellulosics: microbial, chemical, and enzymatic aspects of the fungal attack lignin, INTERNATIONAL MICROBIOLOGY, 8, 195-204.

Nazarpour, F., Abdullah, D. K., Abdullah, N., \& Zamiri, R. (2013). Evaluation of Biological Pretreatment of Rubberwood with White Rot Fungi for Enzymatic Hydrolysis. Materials, 6, 2059-2073. http://dx.doi.org/10.3390/ma6052059

Octavio, L. C., Irma, P. P., Ricardo, B. R., \& Francisco, V. O. (2006). Laccases. In Guevara-González, R.G., Torres-Pacheco, I., Advances in Agricultural and Food Biotechnology, Research Signpost, India.

Palm Oil. (2014). Retrieved September 28, 2014, from http://www.indonesia-investments.com/doing-business/commodities/palm-oil/item166

Pandey, A., Soccol, C. R., \& Laroche, C. (2008). Current development in solid state fermentation. Springer. Asiatech Publisher Inc. New Delhi. http://dx.doi.org/10.1007/978-0-387-75213-6

Risdianto, H., Setiadi, T., Suhardi, S. H., \& Niloperbowo, W. (2007). Pemilihan Spesies Jamur dan Media Imobilisasi untuk Produksi Enzim Ligninolitik. Prosiding Seminar Nasional Rekayasa Kimia dan Proses

Risdianto, H., Sofianti, E., Suhardi, S. H., \& Setiadi, T. (2012). Optimisation of laccase production using white rot fungi and agriculture wastes in solid state fermentation. ITB Journal of Engineering Science, 44B(2), 93-106.

Risdianto, H., Suhardi, S. H., Setiadi, T., \& Kokugan, T. (2010). The Influence of Temperature on Laccase Production in Solid State Fermentation by using White Rot Fungus Marasmius sp. Proceeding of The 1st International Seminar on Fundamental \& Application of Chemical Engineering. http://dx.doi.org/10.5614/itbj.eng.sci.2012.44.2.1

Scott, G. M., Akhtar, M., Myers, G. C., Sykes, M. S., \& Swaney, R. E. (2001). An update on biopulping commercialization. Proceedings of the 3rd ecopapertech conference; 2001 June 04-08; Helsinki, Finland. Espoo, Finland: Oy Keskusiaboratorio-CentrallaboratoriumAB: 37-43.

Singh, P., Sulaiman, O., Hashim, R., Peng, L. C., \& Singh, R. P. (2013). Evaluating biopulping as an alternative application on oil palm trunk using the white-rot fungus Trametes versicolor. International Biodeterioration \& Biodegradation, 82, 96-103. http://dx.doi.org/10.1016/j.ibiod.2012.12.016

Singhal, A. (2008). Optimization of process parameters for biopulping and treatment of pulp and paper mill effluent. Thesis. Jawaharlal Nehru University, India.

Singhal, A., Jaiswal, P. K., Jha, P. K., Thapliyal, A., \& Thakur, I. S. (2013). Assessment of Cryptococcus albidus for biopulping of eucalyptus. Preparative Biochemistry and Biotechnology, 43(8), 735-749. http://dx.doi.org/10.1080/10826068.2013.771784

Sudiyani, Y., Styarini, D., Triwahyuni, E., Sudiyarmanto, Sembiring. K. C., Aristiawan, Y., Abimanyu, H., \& Han, M. H. (2013). Utilization of biomass waste empty fruit bunch fiber of palm oil for bioethanol production using pilot-scale unit. Energy Procedia, 32, 31-38. http://dx.doi.org/10.1016/j.egypro.2013.05.005

Visvanathan, C., Setiadi, T., Herath, G., \& Han, S. (2009). Eco - Industrial Clusters in Urban - Rural Fringe Areas: A strategic Approach for Integrated Environmental and Economic Planning. Asian Institute of Technology.

Wan, C., \& Li, Y. (2012). Fungal pretreatment of lignocellulosic biomass. Biotechnology Advances, 30, 1447-1457. http://dx.doi.org/10.1016/j.biotechadv.2012.03.003

Wanrosli, W. D., Law, K. N., Zainuddin, Z., \& Asro, R. (2004a). Effect of pulping variables on the characteristics of oil-palm frond-fiber. $\quad$ Bioresour. Technol., 93(3), 233-240. http://dx.doi.org/10.1016/j.biortech.2003.11.016

Wanrosli, W. D., Zainuddin, Z., \& Lee, L. K. (2004b). Influence of pulping variables on the properties of Elaeis guineensis soda pulp as evaluated by response surface methodology. Wood Science and Technology, 38(3), 191-205. http://dx.doi.org/10.1007/s00226-004-0227-7

Yadav, R. D., Chaudhry, S., \& Dhiman, S. S. (2010). Biopulping and its potential to reduce effluent load from 
bleaching of hardwood kraft pulp. Bioresources, 5(1), 159-171.

\section{Copyrights}

Copyright for this article is retained by the author(s), with first publication rights granted to the journal.

This is an open-access article distributed under the terms and conditions of the Creative Commons Attribution license (http://creativecommons.org/licenses/by/3.0/). 